\title{
Synthesis of Acetic Acid by Catalytic Oxidation of Butenes (Part 1)*
}

\author{
Oxidation of $\boldsymbol{n}$-Butenes and Isobutene to Acetic Acid over \\ Binary Oxide Catalysts Containing Vanadium Pentoxide \\ by Takashi Y'amashita**, Sadayoshi Ninagawa** and Tetsuya Kato**
}

\begin{abstract}
Summary: The probability of acetic acid synthesis from n-butenes and isobutene was studied with $\mathrm{V}_{2} \mathrm{O}_{5}$-binary catalysts. As a second component, following atoms were added to $\mathrm{V}_{2} \mathrm{O}_{5}$ in the form of oxide or metal; Rh, B, Cr, Nb, Zn, Pd, Ta, Zr, Si, Ni, Ge, Fe, Ca, Pl, W, Li, Cd, As, Co, Te, $\mathrm{Mg}, \mathrm{Mn}, \mathrm{Mlo}, \mathrm{Cu}, \mathrm{Ag}, \mathrm{P}, \mathrm{Ba}, \mathrm{T} i, \mathrm{Sn}, \mathrm{Al}$, and $\mathrm{Sb}$.

In the presence of water, $n$-butenes and isobutene were oxidized to acetic acid with more than $40 \%$ selectivity based on the carbon atom at about $100 \%$ conversion of each butene with air containing $3 \%$ of butene over $V-C r(3 / 7), V-R h(8 / 2), V-B(5 / 5)$ and $V-N b(5 / 5)$ catalysts at $270 \sim 310^{\circ} \mathrm{C}$.

Acetaldehyde, acetone, formaldehyde, maleic acid, formic acid, propionic acid, acrylic acid and citoraconic acid were obtained in low yields from n-butenes.

On the other hand, from isobutene methacrylic acid and isobutylic acid were formed in addition to above by-products in low yields.

As to the reaction path, acetic acid was considered to be formed via hydration of butenes to form an alcoholic intermediate ${ }^{1)}$, followed by oxydehydrogenation on the catalyst which had some different active sites to induce other reactions at the same time.
\end{abstract}

\section{Introduction}

In the industrial production of acetic acid, some processes have been reported: the oxidation of acetaldehyde formed from ethylene with $\mathrm{PdCl}_{2}-\mathrm{CuCl}_{2}$ type catalysts and the liquid phase oxidation of naphtha or butane and the carboxylation of methyl alcohol. In these processes, the last process seems to be most economical.

In 1966, Brockhaus found a new process of acetic acid synthesis with good yields by vapor phase catalytic oxidation of $n$-butenes with $\mathrm{V}_{2} \mathrm{O}_{5}$-binary oxide catalysts such as $\mathrm{V}-\mathrm{Ti}, \mathrm{V}-\mathrm{Sn}$, $\mathrm{V}-\mathrm{Sb}$ and $\mathrm{V}-\mathrm{Al}^{2}$ ). However, this process required separation of isobutene from $n$-butenes. However, it would be economical if mixed butenes after recovering butadiene from $\mathrm{C}_{4}$ fraction could be used as the starting materials.

On the other hand, the synthesis of acetic acid in a yield of $20 \%$ from isobutene by catalytic gas phase oxidation over $\mathrm{V}_{2} \mathrm{O}_{5}$ catalyst is known

* Received June 8, 1976.

(This Paper was Presented in part at the 24 th Annual Meeting of the Chemical Society of Japan at Osaka, April, 1971.)

** Central Research Laboratories, Ajinomoto Co., Inc. (Suzuki-cho, Kawasaki-ku, Kawasaki, Kanagawa 210) only by Bretton ${ }^{3)}$. Recently many catalysts have been mentioned in patents ${ }^{4}$ ) to synthesize acetic acid from $n$-butenes and isobutene.

Accordingly, we investigated to find effective catalyst systems consisting of $\mathrm{V}_{2} \mathrm{O}_{5}$ and another element for the synthesis of acetic acid from $n$ butenes and isobutene. At the same time, the mechanism of acetic acid formation from butenes over these catalysts was elucidated.

\section{Experimental}

\subsection{Apparatus and Procedure}

$n$-Butenes and isobutene were supplied by Takachiho Chem. Ind. Co.. Air containing $3 \%$ olefin and water was introduced into a preheating tube made of Pyrex glass $(25 \mathrm{~mm}$ i.d. and $20 \mathrm{~cm}$ length), which was electrically heated and maintained at ca. $200^{\circ} \mathrm{C}$ and was jointed with a reactor with a greaseless joint. This joint was convenient at the time the catalyst needed to be exchanged with another. The reactor was made of Pyrex glass $(25 \mathrm{~mm}$ i.d. and $10 \mathrm{~cm}$ in length) and a thermometer well was located at the center of the reactor. The reaction temperature was controlled by heating the tube with an electric heater.

The effluent gas from the reactor was led

Volume 18, No. 2, November 1976 
Table 1 Catalyst Preparation

\begin{tabular}{|c|c|c|c|}
\hline$x$ & A & B & C \\
\hline $\begin{array}{l}\mathrm{Cr}-1 \\
\mathrm{Rh} \\
\mathrm{B} \\
\mathrm{Zn} \\
\mathrm{Si} \\
\mathrm{iv} \\
\mathrm{Li} \\
\mathrm{Ag} \\
\mathrm{Pb} \\
\mathrm{Ba} \\
\mathrm{Cu} \\
\mathrm{Mo}\end{array}$ & $\begin{array}{l}\mathrm{NH}_{3} \mathrm{VO}_{3} / \mathrm{OA} \text { aq. } \\
\mathrm{V}_{2} \mathrm{O}_{5} / \mathrm{HCl} \text { aq. } \\
\mathrm{NH}_{4} \mathrm{VO}_{3} / \text { aq. } \\
\mathrm{NH}_{4} \mathrm{VO}_{3} / \text { aq. } \\
\mathrm{NH}_{4} \mathrm{VO}_{3} / \mathrm{OA} \text { aq. } \\
\mathrm{V}_{2} \mathrm{O}_{6} / \mathrm{EA} \text { aq. } \\
\mathrm{NH}_{4} \mathrm{VO}_{3} \\
\mathrm{NH}_{4} \mathrm{VO}_{3} \\
\mathrm{NH}_{4} \mathrm{VO}_{3} \\
\mathrm{NH}_{4} \mathrm{VO}_{3} \\
\mathrm{NH}_{4} \mathrm{VO}_{3} \\
\mathrm{NH}_{4} \mathrm{VO}_{3} / \mathrm{OA} \text { aq. }\end{array}$ & $\begin{array}{l}\mathrm{CrO}_{3} / \mathrm{OA} \text { aq. } \\
\mathrm{RhCl}_{3} / \mathrm{aq} . \\
\mathrm{H}_{3} \mathrm{BO}_{3} \text { aq. } \\
\mathrm{ZnCO}_{3} \text { aq. } \\
\mathrm{SiO}_{2} \mathrm{gel} \\
\mathrm{WO}_{8} / \mathrm{EA} \text { aq. } \\
\mathrm{LiCl}_{\mathrm{NH}_{3}} \\
\mathrm{AgNO}_{3} \text { aq. } \\
\mathrm{Pb}\left(\mathrm{NO}_{3}\right)_{2} \text { aq. } \\
\mathrm{Ba}\left(\mathrm{OH}_{2} \text { aq. }\right. \\
\mathrm{CuCO})_{3} \cdot \mathrm{Cu}(\mathrm{OH})_{2} \\
\left(\mathrm{NH}_{4}\right)_{6} \mathrm{MO}_{7} \mathrm{O}_{24} / \mathrm{OA}^{2} \text { aq. }\end{array}$ & $\begin{array}{l}\text { Mix. of A and B was evaporated to dry- } \\
\text { ness. }\end{array}$ \\
\hline $\begin{array}{l}\mathrm{Cr}-2 \\
\mathrm{Nb} \\
\mathrm{Ta} \\
\mathrm{Zr} \\
\mathrm{Fe} \\
\mathrm{Ti} \\
\mathrm{Sb}\end{array}$ & $\begin{array}{l}\mathrm{V}_{2} \mathrm{O}_{5} / \mathrm{OA} \text { aq. } \\
\mathrm{V}_{2} \mathrm{O}_{5} / \mathrm{HCl} \text { aq. } \\
\mathrm{V}_{2} \mathrm{O}_{5} / \mathrm{HCl} \text { aq. } \\
\mathrm{V}_{2} \mathrm{O}_{5} / \mathrm{HCl} \text { aq. } \\
\mathrm{V}_{2} \mathrm{O}_{5} / \mathrm{HCl} \text { aq. } \\
\mathrm{V}_{2} \mathrm{O}_{5} / \mathrm{HCl} \text { aq. } \\
\mathrm{V}_{2} \mathrm{O}_{5} / \mathrm{HCl} \text { aq. }\end{array}$ & $\begin{array}{l}\mathrm{Ac}_{2} \mathrm{Cr} \text { aq. } \\
\mathrm{Nb}_{2} \mathrm{O}_{5} / \mathrm{HCl} \text { aq. } \\
\mathrm{TaCl}_{5} / \mathrm{HCl} \text { aq. } \\
\mathrm{ZrCl}_{4} / \mathrm{HCl} \text { aq. } \\
\mathrm{FeCl}_{3} / \mathrm{HCl} \text { aq. } \\
\mathrm{TiCl}_{4} / \mathrm{HCl} \text { aq. } \\
\mathrm{SbCl}_{3} / \mathrm{HCl} \text { aq. }\end{array}$ & $\begin{array}{l}\text { Mix. of } \mathrm{A} \text { and } \mathrm{B} \text { was neutralized with } \\
\mathrm{NH}_{3} \text { and the precipitate was washed } \\
\text { with water. }\end{array}$ \\
\hline $\begin{array}{l}\mathrm{Ni} \\
\mathrm{Sn}\end{array}$ & $\begin{array}{l}\mathrm{V}_{2} \mathrm{O}_{5} / \text { EA aq. } \\
\mathrm{V}_{2} \mathrm{O}_{5} / \text { EA aq. }\end{array}$ & $\begin{array}{l}\mathrm{NiCl}_{2} \text { aq. } \\
\mathrm{SnCl}_{2} \text { aq. }\end{array}$ & $\begin{array}{l}\text { Mix. of } A \text { and } B \text { was neutralized with } \\
\text { EA or } H C l \text { and the precipitate was } \\
\text { washed with water. }\end{array}$ \\
\hline $\begin{array}{l}\mathrm{Pd} \\
\mathrm{Pt} \\
\mathrm{Bi} \\
\mathrm{Ge} \\
\mathrm{Mn} \\
\mathrm{Te}\end{array}$ & $\begin{array}{l}\mathrm{V}_{2} \mathrm{O}_{5} / \mathrm{HCl} \text { aq. } \\
\mathrm{V}_{2} \mathrm{O}_{6} / \mathrm{HCl} \text { aq. } \\
\mathrm{V}_{2} \mathrm{O}_{5} / \mathrm{HCl} \text { aq. } \\
\mathrm{V}_{2} \mathrm{O}_{5} / \mathrm{HCl} \text { aq. } \\
\mathrm{V}_{2} \mathrm{O}_{5} / \mathrm{HCl} \text { aq. } \\
\mathrm{V}_{2} \mathrm{O}_{5} / \mathrm{HCl} \text { aq. }\end{array}$ & $\begin{array}{l}\mathrm{FdCI}_{2} / \mathrm{HCl} \text { aq. } \\
\mathrm{HPtCI}_{5} / \mathrm{HCl} \text { aq. } \\
\mathrm{BiCI}_{3} / \mathrm{HCl} \text { aq. } \\
\mathrm{GeCI}_{4} / \mathrm{HCl} \text { aq. } \\
\mathrm{Ac}_{2} \mathrm{Mn}_{\mathrm{aq} .} \\
\mathrm{TeO}_{2} / \mathrm{HCl} \text { aq. }\end{array}$ & $\begin{array}{l}\text { Mix. of } A \text { and } B \text { was neutralized with } \\
\mathrm{NH}_{3} \text { aq. and the solution was evapo- } \\
\text { rated to dryness. }\end{array}$ \\
\hline $\begin{array}{l}\mathrm{Ca} \\
\mathrm{Mg} \\
\mathrm{Cd} \\
\mathrm{Co}\end{array}$ & $\begin{array}{l}\mathrm{V}_{2} \mathrm{O}_{5} / \mathrm{EA} \text { aq. } \\
\mathrm{V}_{2} \mathrm{O}_{5} / \mathrm{EA} \text { aq. } \\
\mathrm{V}_{2} \mathrm{O}_{5} / \mathrm{EA} \text { aq. } \\
\mathrm{V}_{2} \mathrm{O}_{5} / \mathrm{EA} \text { aq. }\end{array}$ & $\begin{array}{l}\mathrm{CaCl}_{2} / \mathrm{aq} . \\
\mathrm{MgCl}_{2} / \mathrm{aq} . \\
\mathrm{Ac}_{2} \mathrm{Cd}_{\mathrm{aq}} \\
\mathrm{Co}\left(\mathrm{NO}_{3}\right)_{2} / \mathrm{aq} .\end{array}$ & $\begin{array}{l}\text { Mix. of } A \text { and } B \text { was neutralized wtih } \\
\text { EA and the solution was evaporated to } \\
\text { dryness. }\end{array}$ \\
\hline
\end{tabular}

EA; Ethanolamine, OA; Oxalic acid, Ac; $\mathrm{CH}_{3} \mathrm{COO}$

through a water condenser and then to a trap cooled with ice water. The condensed products and the water in the scrubber were made up to $100 \mathrm{ml}$ for analysis as will be described later.

The outlet gas was analyzed as described eleswhere. The experimental data of a catalyst was obtained after air oxidation of sec-butyl alcohol $(s e c-\mathrm{BuOH})$ with water at $250 \sim 300^{\circ} \mathrm{C}$ under atmospheric pressure for $10 \sim 15 \mathrm{hr}$.

In the screening of a catalyst, its activity was measured at intervals of about $20^{\circ} \mathrm{C}$ and the critical temperature at which total acid was obtained in the maximum yield was taken. The reaction temperature was measured at the highest position of the catalyst bed.

When ethylene, propylene, butadiene and butene were oxidized, 1 vol $\%$ of $n$-butane was mixed to the reaction gas. Being stable to oxidation under the investigated conditions, $n$ butane was used as a standard gas for gaschromatographic analysis of olefins. In the oxidation of sec-BuOH, methyl ethyl ketone (MEK), diacetyl, isopropanol $(i-\mathrm{PrOH})$, and acetaldehyde $(\mathrm{AcH})$, $1.0 \mathrm{~mol} / \mathrm{l}$ aqueous solution of these compounds was fed with air at a constant rate.

\subsection{Prepatation of Catalysts}

All chemicals were reagent grade and were used without further purification. Table 1 shows the methods of preparation of the various catalysts. Solution A and solution B were treated with a preparation $\mathrm{C}$. The resulting product was dried and calcinated to oxide or metal in air at $500 \sim 550^{\circ} \mathrm{C}$ for $5 \mathrm{hr}$. The catalysts thus obtained were used in sizes from 16 to 30 mesh. When the calcinated catalyst was a powder, it was pressed at $10 \sim 15 \mathrm{t} / \mathrm{cm}^{2}$ and crashed to the size of from 16 to 30 mesh. $\quad \mathrm{V}_{2} \mathrm{O}_{5}$ catalyst was prepared as follows. An aqueous solution of $\mathrm{V}_{2} \mathrm{O}_{5}$ in hot oxalic acid was concentrated and the resulting residue was calcinated in air at $500 \sim 550^{\circ} \mathrm{C}$ for $5 \mathrm{hr} . \quad \mathrm{V}_{2} \mathrm{O}_{3}$ catalyst was prepared by reduction of the $\mathrm{V}_{2} \mathrm{O}_{5}$ catalyst with hydrogen at $500^{\circ} \mathrm{C}$ for $5 \mathrm{hr}$. A microspherical catalyst of $\mathrm{V}$-Cr $(3: 7)$ was prepared as follows.

An aqueous solution of vanadyl oxalate and acetyl chromate was adjusted to $\mathrm{pH} 10$ with conc. $\mathrm{NH}_{4} \mathrm{OH}(28 \%)$ and then digested over- 
night at room temperature. The resulting precipitate was filtered and washed. This gel was allowed to $\mathrm{mix}$ with an aluminium hydroxide gel free from chloride ion using a colloidal mill with water, and the resulting homogeneous gel was dried with a spray dryer to a dark-green microspherical powder, which was calcinated in air at $500 \sim 550^{\circ} \mathrm{C}$ for $5 \mathrm{hr}$.

\subsection{Analysis}

In the screening of a catalyst, gas products, total acid, $\mathrm{AcH}$ and acetic acid $(\mathrm{AcOH})$ were quantitatively analyzed as follows. The difference between the total acid and $\mathrm{AcOH}$ was regarded as maleic acid (MA) in the oxidation of $n$-butene or $s e c-\mathrm{BuOH}$ and as citraconic acid (CA) in the oxidation of isobutene. In order to analyze the reaction products rigorously the following methods were used.

Total acid; titrated with $0.1 \mathrm{~N} \mathrm{NaOH}$ solution.

$\mathrm{CO}$; gas chromatographed over molecular sieve column.

$\mathrm{CO}_{2} ;$ gas chromatographed over silica gel column.

Olefins and $n$-butane; gas chromatographed over V. Z. 7.

Folmaldehyde; titrated with chromotropic acid $^{5}$.

$\mathrm{AcH}$, acetone, sec-BuOH, MEK, diacetyl; gas chromatographed over $3 \%$ carbowax $20 \mathrm{M}$ on Porapak Q.

Formic acid; titrated with potassium permanganate after steam distillation ${ }^{6}$.

$\mathrm{AcOH}$, propionic acid, acrylic acid, MA, methacrylic acid (MAA), isobutyric acid and $\mathrm{CA}$; gas chromatographed over $5 \%$ FFAP/Flusin $\mathrm{T}$ with glass column.

MA, MMA and CA; quantitatively analyzed UV spectrum at $212 \mathrm{~nm}$. $\varepsilon=4,400$ (MAA), 10,550 (MA), 7,500 (CA).

The reaction products were separated by gas chromatography and identified by IR, NMR and gas chromatography using another column. The yield and selectivity of each product were calculated based on the carbon atom. In the oxidation of sec-BuOH, conversion and selectivity were calculated based on the consumption of $n$-butenes formed from sec-BuOH, because sec-BuOH was completely dehydrated to $n$ butenes which was attained in equilibrium under the oxidation conditions.

Volume 18, No. 2, November 1976

\section{Results and Discussion}

\subsection{Oxidation of sec-BuOH over $\mathrm{V}_{2} \mathrm{O}_{5}-\mathrm{X}$ Catalysts}

To find a catalyst which has good selectivity to $\mathrm{AcOH}$ from sec-BuOH, many $\mathrm{V}_{2} \mathrm{O}_{5}$-binary catalysts systems which contained a second component up to $20 \%$ based on the metal were tested. In each case, sec-BuOH was completely dehydrated to $n$-butene isomers under the reaction conditions. Apparently the same results were obtained in the oxidation of either sec$\mathrm{BuOH}$ or $n$-butenes.

Selectivity to products at $90 \%$ conversion of $n$-butenes with many catalysts are shown in Fig. 1 3. The second components which increased the selectivity to $\mathrm{AcOH}$ and $\mathrm{AcH}$ compared with $\mathrm{V}_{2} \mathrm{O}_{5}$ catalyst were in the order: $\mathrm{Rh}>\mathrm{Ta}>\mathrm{Ca}>\mathrm{W}>\mathrm{Si}, \mathrm{Nb}, \mathrm{Cr}>\mathrm{Pd}, \mathrm{Li}, \mathrm{B}, \mathrm{V}>$

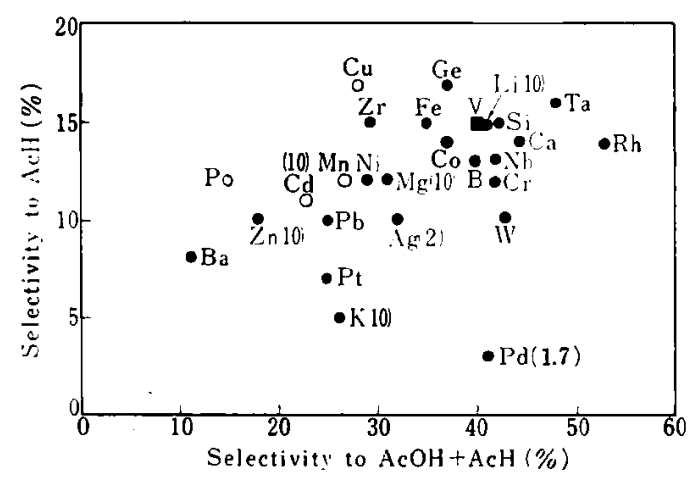

Cat.; $4 \mathrm{ml}$, Feed; sec-BuOH : air : $\mathrm{H}_{2} \mathrm{O}=1: 41: 58$, $\mathrm{SV}=6,200 \mathrm{hr}^{-1}$

; $n$-Butene conversion was $90 \%$

0 ; $n$-Butene conversion was $70 \%$

( ); Atomic percentage of $\mathrm{X}$ in $\mathrm{V} / \mathrm{X}$ catalyst except $X=20 \%$

Fig. 1 Selectivity to $\mathrm{AcOH}$ and $\mathrm{AcH}$ from sec-BuOH over $\mathrm{V} / \mathrm{X}(8 / 2)$ Catalysts

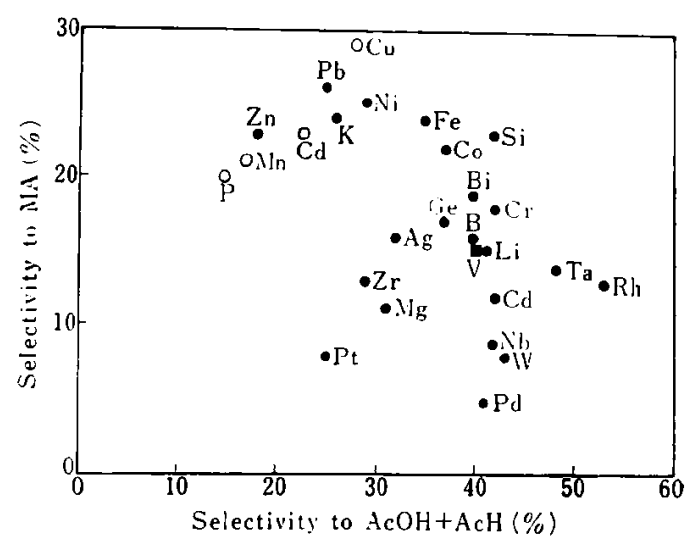

Reaction conditions and notations as in Fig. 1

Fig. 2 Selectivity to $\mathrm{AcOH}+\mathrm{AcH}$ and MA from sec-; $\mathrm{BuOH}$ over $\mathrm{V} / \mathrm{X}(8 / 2)$ 


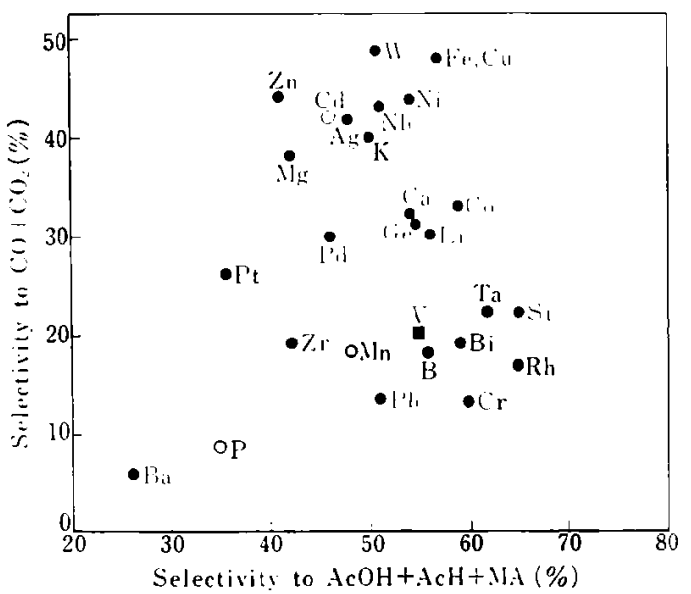

Reaction conditions and notation as in Fig. 1

Fig. 3 Relationship between the Selectivities to $\mathrm{CO}$ $+\mathrm{CO}_{2}$ and $\mathrm{AcOH}+\mathrm{AcH}+\mathrm{MA}$ from sec-Bu$\mathrm{OH}$ over $\mathrm{V} / \mathrm{X}(8 / 2)$

Co, Ge, Fe (Fig. 1). On the other hand, many second components which increased the selectivity to MA were in the order: $\mathrm{Cu}>\mathrm{Pb}>\mathrm{Ni}>$ $\mathrm{K}>\mathrm{Zn}$, Si, C.d, Fe, Co, $\mathrm{Mn}>\mathrm{P}>\mathrm{Bi}>\mathrm{Cr}>\mathrm{Ge}>\mathrm{B}$, $\mathrm{Ag}>\mathrm{V}$ (Fig. 2). Complete combustion to $\mathrm{CO}$ and $\mathrm{CO}_{2}$ was depressed in the case of $\mathrm{Ba}, \mathrm{P}$, $\mathrm{Pb}, \mathrm{Cr}, \mathrm{Rh}, \mathrm{Bi}$ and $\mathrm{B}$ (Fig. 3 ;

Although some higher selective catalysts than $\mathrm{V}_{2} \mathrm{O}$; catalyst were found to form $\mathrm{AcOH}$ and $\mathrm{AcH}$ from $n$-butenes, the maximum selectivity to AcOH was only $39^{\circ} \%$ with V-Rh (8:2) catalyst. Economically, this level of selectivity is unsatisfactory.

As selectivity to some useful products from olefin generally changes with the composition of a catalyst, all above binary catalysts containing a wider range of second elements were tested. With almost all of the catalysts, sec-BuOH was dehydrated to $n$-butenes and MEK was not detected. With V-Co and V-Rh catalysts, MEK was exceptionally found in the product when the second component exceeded over $30 \sim 40 \%$ of the metal atom. In these cases, different results were obtained in the oxidation of sec$\mathrm{BuOH}$ and $n$-butenes, about which the authors will report in a subsequent paper.

Figure 4 shows the optimal compositions of the various binary catalysts over which sec-BuOH formed $\mathrm{AcOH}$ with the maximum selectivity at $80 \sim 100 \%$ conversion of $n$-butenes formed from sec-BuOH. The selectivity to $\mathrm{MA}$ is shown in the same Fig.. AcOH was formed in good yields fiom sec-BuOH with the following catalysts: V-Rh (5:5), V-Cir $(3: 7), \mathrm{V}-\mathrm{Ti}(4: 6)$,

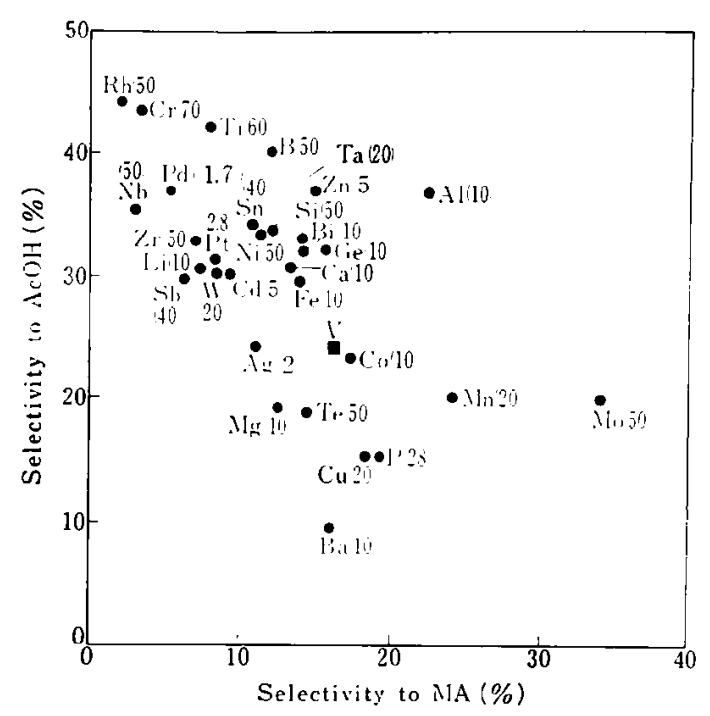

( ); Atomic percentage of a second component in V/X Catalyst, Cat.; $4 \mathrm{ml}$, Feed; sec-BuOH : air : $\mathrm{H}_{2} \mathrm{O}=1: 41: 58, \mathrm{SV}=6,200 \mathrm{hr}^{-1}$

Fig. 4 Optimal Composition of Each Binary Catalyst giving $\mathrm{AcOH}$ with the Maximum Selectivity from sec-BuOH

V-B (5 : 5), V-Pd (98.3: 1.7) and V-Zn (95:5). With V-Gr $(3: 7)$ catalyst $n$-butenes and sec$\mathrm{BuOH}$ gave $\mathrm{AcOH}$ with the maximum selectivity of $47 \%$ at $98 \%$ conversion of $n$-butenes. These results indicate that $\mathrm{MA}$ was obtained in small quantities over these catalysts, the active site for allylic type oxidation of olefin still remained on the catalysts.

The relationship between the composition of V-Cir catalysts and the selectivity of products is shown in Fig. 5. The temperatures in the Fig. are the optimal values at which $n$-butenes gave the maximum yields of total acid. The V-B catalyst was very hard before use, but it gradually became porous and fragile after several hours of reaction. Almost all of the $\mathrm{B}_{2} \mathrm{O}_{3}$ in the catalyst had evaporated with steam, and the content of boron was only $100 \sim 150$ ppm at the time the activity of the catalyst was measured. In spite of the loss of $\mathrm{B}_{2} \mathrm{O}_{3}$ from the $\mathrm{V}-\mathrm{B}$ catalyst, the selectivity to $\mathrm{AcOH}$ increased to $54^{\circ} \%$ over the $\mathrm{V}-\mathrm{B}(1: 1)$ catalyst from $25^{\circ} \circ$ over $\mathrm{V}_{2} \mathrm{O}_{5}$ catalyst. Whether the role of boric acid is mechanical effect such as increasing surface area or essential for the appearance of the active site was not investigated, but the result obtained seems to be of interest in the search of more effctive catalysts.

\subsection{Oxidation of Isobutene}

A number of catalysts have been proposed 
Table 2 Oxidation of Isobutene

\begin{tabular}{|c|c|c|c|c|c|c|}
\hline \multirow{2}{*}{ Cat. } & \multirow{2}{*}{$\begin{array}{c}\text { Temp. } \\
\left({ }^{\circ} \mathrm{C}\right)\end{array}$} & \multirow{2}{*}{$\begin{array}{c}\mathrm{SI} \\
\left(\mathrm{hr}^{-1}\right)\end{array}$} & \multirow{2}{*}{$\begin{array}{c}\text { Conv. } \\
(\%)\end{array}$} & \multicolumn{3}{|c|}{ Selectivity } \\
\hline & & & & $\underset{(\%)}{\mathrm{AcOH}}$ & $\begin{array}{c}\mathrm{CA} \\
(\%)\end{array}$ & $\underset{(\%)}{\mathrm{CO}+\mathrm{CO}_{2}}$ \\
\hline$V-\operatorname{Cr}(5: 5)^{a)}$ & $\begin{array}{l}275 \\
299\end{array}$ & $\begin{array}{l}3,100 \\
6,200\end{array}$ & $\begin{array}{l}98.8 \\
97.7\end{array}$ & $\begin{array}{l}47.7 \\
37.7\end{array}$ & $\begin{array}{l}7.6 \\
5.4\end{array}$ & $\begin{array}{l}36.5 \\
48.5\end{array}$ \\
\hline $\begin{array}{l}\mathrm{V}-\mathrm{B}(5: 5) \\
\mathrm{V}-\mathrm{Rh}(8: 2) \\
\mathrm{V}-\mathrm{Nb}(5: 5) \\
\mathrm{V}-\mathrm{Zr}(5: 5)\end{array}$ & $\begin{array}{l}306 \\
305 \\
275 \\
285 \\
298\end{array}$ & $\begin{array}{l}3,100 \\
3,100 \\
3,100 \\
3,100 \\
3,100\end{array}$ & $\begin{array}{l}99.3 \\
97.5 \\
96.2 \\
96.2 \\
99.0\end{array}$ & $\begin{array}{l}43.7 \\
43.0 \\
42.3 \\
39.7 \\
31.1\end{array}$ & $\begin{array}{l}5.3 \\
3.8 \\
2.6 \\
2.4 \\
5.8\end{array}$ & $\begin{array}{l}46.5 \\
50.7 \\
42.8 \\
56 \\
61\end{array}$ \\
\hline $\begin{array}{l}\text { V-Zn }(95: 5) \\
\mathrm{V}-\mathrm{Ni}(5: 5) \\
\mathrm{V}-\mathrm{Fe}(9: 1) \\
\mathrm{V}-\mathrm{Ti}(5: 5) \\
\mathrm{V}-\mathrm{Sn}(6: 4) \\
\mathrm{V}-\mathrm{Bi}(9: 1) \\
\mathrm{V}-\mathrm{Pd}(98.3: 1.7) \\
\mathrm{V}-\mathrm{Li}(9: 1) \\
\mathrm{V}-\mathrm{Pt}(97.2: 2.8)\end{array}$ & $\begin{array}{l}268 \\
305 \\
290 \\
265 \\
300 \\
322 \\
285 \\
335 \\
290\end{array}$ & $\begin{array}{l}3,100 \\
3,100 \\
3,100 \\
3,100 \\
3,100 \\
3,100 \\
3,100 \\
3,100 \\
3,100\end{array}$ & $\begin{array}{r}99.5 \\
99.2 \\
96.2 \\
98.0 \\
97.0 \\
98.0 \\
98.9 \\
97.8 \\
100\end{array}$ & $\begin{array}{l}38.8 \\
35.5 \\
37.3 \\
32.0 \\
33.0 \\
34.7 \\
31.9 \\
33.4 \\
23.1\end{array}$ & $\begin{array}{r}3.6 \\
3.0 \\
8.0 \\
3.2 \\
11.2 \\
5.4 \\
1.6 \\
4.5 \\
7.3\end{array}$ & $\begin{array}{l}57 \\
61 \\
45.9 \\
58 \\
\\
38.8 \\
48.5 \\
61 \\
48.2\end{array}$ \\
\hline
\end{tabular}

a) Prepared as $\mathrm{Cr}-1$ in Table 1.

Feed; Isobutene : air : $\mathrm{H}_{2} \mathrm{O}=1.1: 41: 58$

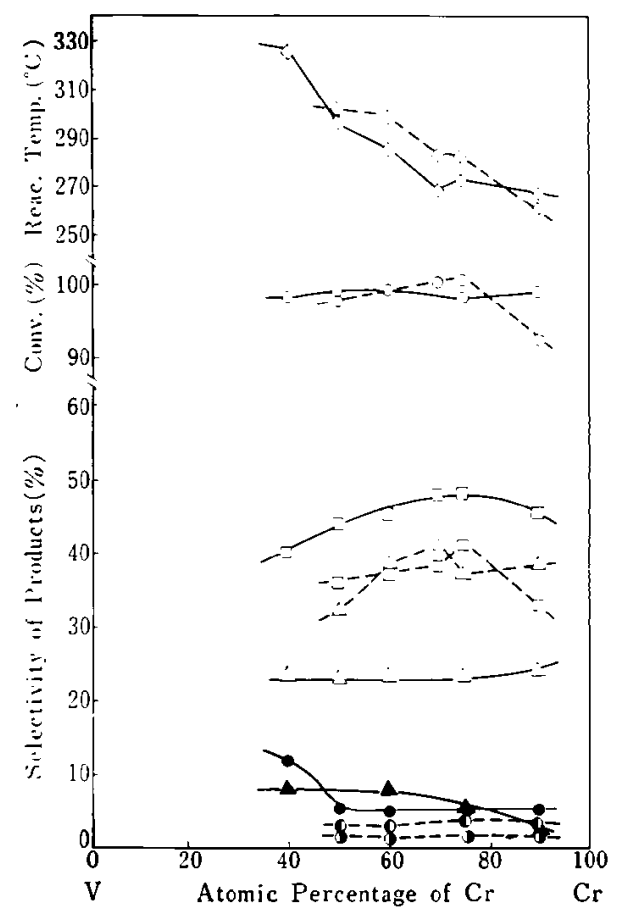

Cat.; $4 \mathrm{ml}$, preparation as $\mathrm{Cr}-2$, Feed; Butene: air : $\mathrm{H}_{2} \mathrm{O}=1.33: 44: 55, \mathrm{SV}=5,600$

$\diamond$; Optimal reaction temp., $O$; Butene conversion, $\square ; \mathrm{AcOH}, \triangle$; $\mathrm{AcH}, \mathrm{O} ; \mathrm{MA}, \triangle$; $\mathrm{CO}+$ $\mathrm{CO}_{2}, \mathbf{O}$; CA, $\mathbf{O}$; Acetone, -; $n$-Butene, ---; Isobutene

Fig. 5 Effect of Atomic Ratio of $\mathrm{V} / \mathrm{Cr}$ Catalyst on $n$-Butene and Isobutene Oxidation

for the synthesis of methacrolein from isobutene through the allylic type intermediate by vapor phase catalytic oxidation.

Interestingly, Bretton found that $\mathrm{AcOH}$ in a yield of $20 \%$ was obtained from isobutene over
$\mathrm{V}_{2} \mathrm{O}_{5}$ catalyst ${ }^{2}$. Futhermore, Kaneko et al. ${ }^{7}$ recently found that isobutene gave $\mathrm{AcOH}$ with selectivity of $15 \sim 17 \%$ over V-Sn-W (1: $1: 0.5)$ catalyst at a low conversion level. From these facts $\mathrm{V}_{2} \mathrm{O}_{5}$ itself has the active site to form $\mathrm{AcOH}$ from isobutene.

With many $\mathrm{V}_{2} \mathrm{O}_{5}$-binary catalysts the oxidation of isobutene was carried out and found that isobutene formed $\mathrm{AcOH}$ in good yields over some catalysts better than $\mathrm{V}_{2} \mathrm{O}_{5}$ catalyst. Acetone and C:A were the main by-products and methacrolein was little found.

Table 2 shows the results of oxidation of isobutene with some catalysts over which $n$ butenes formed $\mathrm{AcOH}$ in good yields. Over $\mathrm{V}$-Cr $(5: 5)$ catalyst isobutene gave $\mathrm{AcOH}$ with the maximum selectivity of $47 \%$. The plot of the selectivity for $\mathrm{AcOH}$ from isobutene and that from $n$-butenes gave nearly a linear relationship except V-Pt catalyst. This result suggests that both butenes give $\mathrm{AcOH}$ on the same active site and with a similar mechanism. The optimum temperature giving $\mathrm{AcOH}$ in the maximum yield from isobutene was higher by about $10 \sim 20^{\circ} \mathrm{C}$ than that from $n$-butene.

The relationship between the catalyst component and the selectivity of products is shown in Fig. 5 for V-Cr catalyst. The optimal molar ratio of $\mathrm{V}$-Cr catalyst to obtain $\mathrm{AcOH}$ with maximum selectivity from $n$-butenes and isobutene respectively was the same composition at the molar ratio V-Cir $(3: 7)$. 
Table 3 Products from Butenes

\begin{tabular}{|c|c|c|c|c|c|}
\hline \multirow{3}{*}{$\begin{array}{l}\text { Cat. } \\
\text { Raw Mate. } \\
\text { Reactor }\end{array}$} & \multicolumn{2}{|c|}{$\mathrm{V} / \mathrm{Cr}(3 / 7)$} & \multicolumn{3}{|c|}{$\mathrm{V} / \mathrm{Cr}(3 / 7) / 20 \% \quad \mathrm{Al}_{2} \mathrm{O}_{3}$} \\
\hline & $n-$ & $i-$ & \multicolumn{2}{|c|}{$n-/ i-(1 / 1)$} & $\operatorname{mix}$. b.c) \\
\hline & \multicolumn{3}{|c|}{ Fixed Bed } & \multicolumn{2}{|c|}{ Fluid. Bed } \\
\hline $\begin{array}{l}\text { Cat. }(\mathrm{ml}) \\
\text { Air }(l / \mathrm{hr}) \\
\mathrm{H}_{2} \mathrm{O} / \mathrm{But} .(-) \\
\text { Temp. }\left({ }^{\circ} \mathrm{C}\right) \\
\text { Conv. }(\%)\end{array}$ & $\begin{array}{c}4 \\
10^{\mathrm{a})} \\
50 \\
267 \\
99.0\end{array}$ & $\begin{array}{c}4 \\
10^{\mathrm{a})} \\
50 \\
268 \\
99.5\end{array}$ & $\begin{array}{c}4 \\
10^{\mathrm{a})} \\
50 \\
296 \\
97.5\end{array}$ & $\begin{array}{c}60 \\
30^{\mathrm{a})} \\
13 \\
242 \\
99.4\end{array}$ & $\begin{array}{l}60 \\
30^{\mathrm{b})} \\
13 \\
240 \\
100\end{array}$ \\
\hline $\begin{array}{l}1 / 4 \mathrm{CO}+\mathrm{CO}_{2} \\
1 / 4 \mathrm{HCOOH} \\
1 / 4 \mathrm{HCHO} \\
1 / 2 \mathrm{AcOH} \\
1 / 2 \mathrm{AcH} \\
3 / 4 \mathrm{C}_{2} \mathrm{H}_{5} \mathrm{COOH} \\
3 / 4 \mathrm{C}_{2} \mathrm{H}_{3} \mathrm{COOH} \\
3 / 4 \mathrm{CH}_{3} \mathrm{COCH} \\
i-\mathrm{C}_{3} \mathrm{H}_{8} \mathrm{COOH} \\
i-\mathrm{C}_{3} \mathrm{H}_{5} \mathrm{COOH} \\
\mathrm{MA} \\
5 / 4 \mathrm{CA}\end{array}$ & $\begin{array}{c}21.0 \\
1.03 \\
1.02 \\
45.4 \\
1.97 \\
0.10 \\
0.36 \\
0.36 \\
\text { tr. } \\
\text { tr. } \\
3.90 \\
0.30\end{array}$ & $\begin{array}{c}37.9 \\
1.15 \\
0.90 \\
39.7 \\
0.17 \\
0.017 \\
0.011 \\
1.91 \\
0.012 \\
0.036 \\
\text { tr. } \\
0.77\end{array}$ & $\begin{array}{c}31.3 \\
1.74 \\
0.90 \\
35.1 \\
2.11 \\
0.013 \\
0.29 \\
1.39 \\
\text { tr. } \\
0.014 \\
6.86 \\
0.10\end{array}$ & $\begin{array}{l}45.0 \\
0.93 \\
-\overline{-} \\
37.5 \\
0.94 \\
\text { tr. } \\
0.0005 \\
1.10 \\
\text { tr. } \\
0.0004 \\
0.68 \\
1.37\end{array}$ & $\begin{array}{c}45.0 \\
0.85 \\
-\overline{1} \\
38.8 \\
0.97 \\
\text { tr. } \\
0.0004 \\
1.36 \\
\operatorname{tr} . \\
0.0003 \\
1.19 \\
1.47\end{array}$ \\
\hline
\end{tabular}

a) Contained 3\% n- or isobutene in air

b) Contained $3.48 \%$ mixed butene in air (3\% as butenes)

c) $n$-Butene $(41.3 \%)$, Isobutene (44.9\%), Butadiene (0.49\%)

3.3 Oxidation of $n$-Butenes, Isobutene and Mixed Butenes and By-products from These Olefins

Normal butenes, isobutene, mixed butenes $(n-: i-=1: 1)$ and spent butene were oxidized over V-Cr catalyst in fixed bed and by fruidization. The results are shown in Table 3. Not only the main products, but also by-products obtained only in small quantities were quantitatively analyzed.

With regard to the by-products from $n$-butenes and isobutene, the following characteristics were observed. Formic acid and formaldehyde were obtained from $n$-butenes and isobutene with the same selectivity. $\mathrm{AcOH}$, propionic acid, acrylic acid and MA were obtained with higer selectivity from $n$-butenes than from isobutene. Acetone, isobutyric acid, MAA and CA were obtained with higher selectivity from isobutene than from $n$-butenes.

Comparing the results of the fixed bed and fruidized, by-products were obtained with lower selectivity for the latter than the formar, and reverse results were observed for overoxidation to $\mathrm{CO}$ and $\mathrm{CO}_{2}$. In the fixed bed experiments, by-products may be stable to overoxidation because of the presence of sufficient quantities of water.

The relationship between the amount of water and selectivity to the products is discussed in another section.
Spent butene and mixed butenes gave $\mathrm{AcOH}$ and by-products with the same selectivity. From the results of oxidation of mixed butenes with these catalysts, spent butene gave $\mathrm{AcOH}$ and by-products in the following weight ratios: $\mathrm{AcOH}$ (100), MA (2-3), CA $(0.2-3), \mathrm{AcH}$ $(1-3)$, acetone $(0.7-1.3)$, formic acid $(2-3)$, formaldehyde $(1-2)$ and other $\mathrm{C}_{3}$ and $\mathrm{C}_{4}$ acid (0.5).

\subsection{Reaction Path of AcOH Formation}

With regard to the reaction path of $\mathrm{AcOH}$ formation from $n$-butenes and isobutene, an alcoholic intermediate that formed via the hydration of butenes is the most plausible path based on the oxidation products of butenes and the similarity of the results of oxidation of olefins and alcohols by Moro-Oka ${ }^{10}$ ) or by Kaneko?) with Co-Mo or V-W-X catalysts as shown in Scheme 1 and 2.

Normal butenes may give sec-BuOH by hydration, which may result in MEK via oxydehydrogenation, and the MEK may be further oxidized to diacetyl. Unstable diacetyl may be hydrated to $\mathrm{AcOH}$ and $\mathrm{AcH}$.

The latter may be easily oxidized to $\mathrm{AcOH}$ (Scheme 1). In the same way, isobutene may give $\mathrm{AcOH}$ via $\mathrm{t}-\mathrm{BuOH}$ and acetone (Scheme 2).

In order to form AcOH from butenes in good yields, a catalyst must have several different active sites for each hydration step and for each oxidation step. Whether $n$-butene can be oxi- 


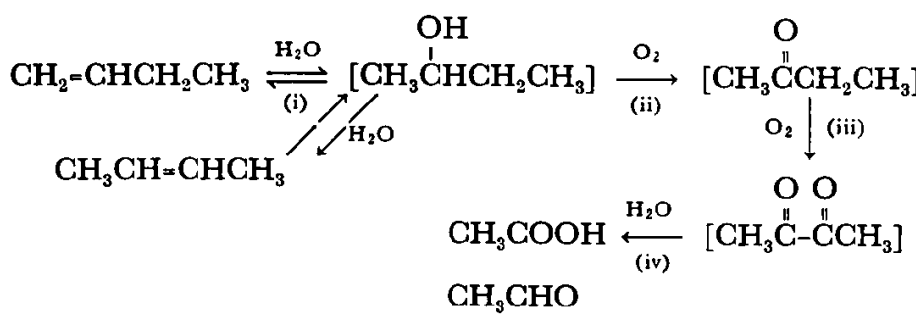

$$
\begin{aligned}
& \text { (v) } \mathrm{O}_{2} \\
& \mathrm{CH}_{3} \mathrm{COOH} \\
& \text { Scheme } 1
\end{aligned}
$$

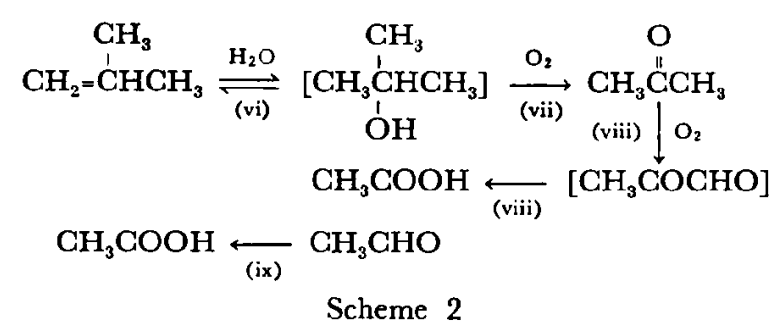

Table 4 Isomerization of 1-Butene

\begin{tabular}{c|c|c|c|c|c|c|c}
\hline & $\begin{array}{c}\mathrm{N}_{2} \\
(l / \mathrm{hr})\end{array}$ & $\begin{array}{c}\mathrm{Air} \\
(\mathrm{l} / \mathrm{hr})\end{array}$ & $\begin{array}{c}\left.\mathrm{H}_{2} \mathrm{O}^{\mathrm{b}}\right) \\
(\mathrm{ml} / / \mathrm{hr})\end{array}$ & $\begin{array}{c}\text { Temp. } \\
\left({ }^{\circ} \mathrm{C}\right)\end{array}$ & \multicolumn{3}{|c}{ Distri. of Butene (\%) } \\
\hline $\left.\mathrm{V}_{2} \mathrm{O}_{3} \mathrm{a}\right)$ & 50 & & & & $1-$ bu. & t-2-bu. & c-2-but. \\
\hline & 50 & & 50 & 300 & 87 & 5 & 8 \\
\hline \\
\hline
\end{tabular}

a) Cat. $4 \mathrm{ml}$ b) As liquid

dized to AcOH over $\mathrm{V}_{2} \mathrm{O}_{5}$ and $\mathrm{V}_{2} \mathrm{O}_{5}$-binary catalysts as expected by the above-mentioned schemes was studied.

\subsubsection{Isomerization of $n$-Butene with $\mathrm{V}_{2} \mathrm{O}_{3}$ and $\mathrm{V}_{2} \mathrm{O}_{5}$ Catalyst}

The isomerization of 1-butene over $\mathrm{V}_{2} \mathrm{O}_{3}$ catalyst began at $260^{\circ} \mathrm{C}$ either in the presence or absence of water in a nitrogen stream. After the oxidation of $\mathrm{V}_{2} \mathrm{O}_{3}$ with air at $350^{\circ} \mathrm{C}$ for $1 \mathrm{hr}$, the isomerization of 1-butene increased from $5.1 \%$ to $12.6 \%$ in the presence of water under nitrogen at $250^{\circ} \mathrm{C}$. In the presence of water and air, it increased to $79 \%$ and the distribution of $n$-butene isomers attained equilibrium (Table 4).

These results suggest that acidity of $\mathrm{V}_{2} \mathrm{O}_{5}$ is greater than that of $\mathrm{V}_{2} \mathrm{O}_{3}$ and that, only with $\mathrm{V}_{2} \mathrm{O}_{5}$ catalyst, water participates in the appearance of acidity, but oxygen plays an important role in the appearance of acidity of the catalyst, that is, the oxidation-reduction system of the

Volume 18, No. 2, November 1976 catalyst may relate to the appearance of acidity of the catalyst.

\subsubsection{Effect of Water on the Selectivity to $\mathrm{AcOH}$}

Generally in a catalytic oxidation of olefins, water effectively depresses the oxidation of the intermediate. In this oxidation reaction, water may be a reagent in the Schemes 1 and 2 and may participate in the appearance of acidity of the catalyst. The object of this study was to determine the minimum amount of water needed to form $\mathrm{AcOH}$ from $n$-butene and isobutene in the maximum yield. The experiment to prove participation of water in the hydration of butenes with V-Cr catalyst was not performed by the tracer technique as had been done in the oxidation of propylene over $\mathrm{SnO}_{2}-\mathrm{MoO}_{3}$ catalyst by $\mathrm{Moro}^{-o k a^{1}}{ }^{1}$. Figure 6 shows the relationship between the amount of water and the selectivity of products with V-Cr $(3: 7)$ catalyst. 


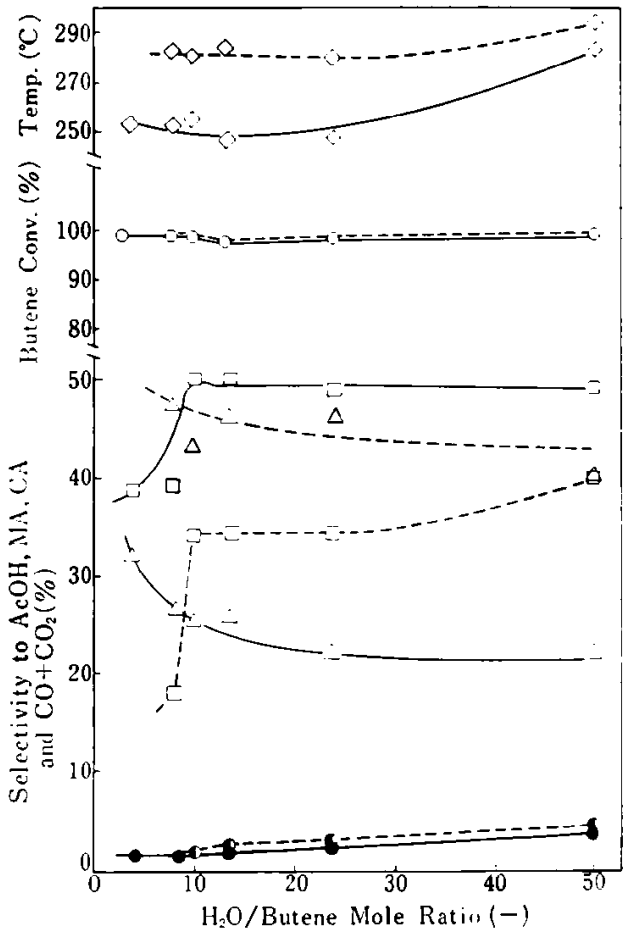

Cat.; $\mathrm{V} / \mathrm{Cr}(3 / 7) 4 \mathrm{ml}$, preparation as $\mathrm{Cr}-2$, Feed; $101 / \mathrm{hr}$ air containing $3 \%$ butene, Notations as in Fig. 5, -; n-Butene, ---; Isobutene

Fig. 6 Effect of Steam Addition on $n$-Butene and Isobutene Oxidation

When the molar ratio of $\mathrm{H}_{2} \mathrm{O}$ /butene was over 10 , both $n$-butene and isobutene gave $\mathrm{AcOH}$ with good selectivity, and deep-oxidation to $\mathrm{CO}$ and $\mathrm{CO}_{2}$ was depressed. The selectivity to MA from $n$-butenes and to CA from isobutene gradually increased from $1.5 \%$ to about $4 \%$.

\subsection{3 n-Butene Conversion and Products Selectivity}

Figure 7 shows the relationship between the conversion of $n$-butene and the selectivity of products over $\mathrm{V}_{2} \mathrm{O}_{5}$ and $\mathrm{V}-\mathrm{Cr}(5: 5)$ catalyst. The following characteristics were observed. (i) $n$-Butenes were oxidizable at lower temperatures over $\mathrm{V}$-Cr $(5: 5)$ than over $\mathrm{V}_{2} \mathrm{O}_{5}$ catalyst by $40 \sim 50^{\circ} \mathrm{C}$. (ii) The selectivity to MA was constant over $\mathrm{V}_{2} \mathrm{O}_{5}$ catalyst, but over $\mathrm{V}$-Cr $(5: 5)$ catalyst it decreased with the increase in conversion of $n$-butenes. These results show that MA is more easily oxidized to $\mathrm{CO}$ and $\mathrm{CO}_{2}$ over $\mathrm{V}$-Cr than over $\mathrm{V}_{2} \mathrm{O}_{5}$ catalyst. (iii) The selectivity to $\mathrm{AcH}$ increased from $10 \%$ $\left(\mathrm{V}_{2} \mathrm{O}_{5}\right)$ to $16 \%$ (V-Cr $\left.5: 5\right)$ at $88 \%$ conversion of $n$-butenes, and it slowly decreased to $5 \sim 6 \%$ at $100^{\circ} \%$ conversion of $n$-butenes. (iv) The selectivity to $\mathrm{AcOH}$ increased with increasing

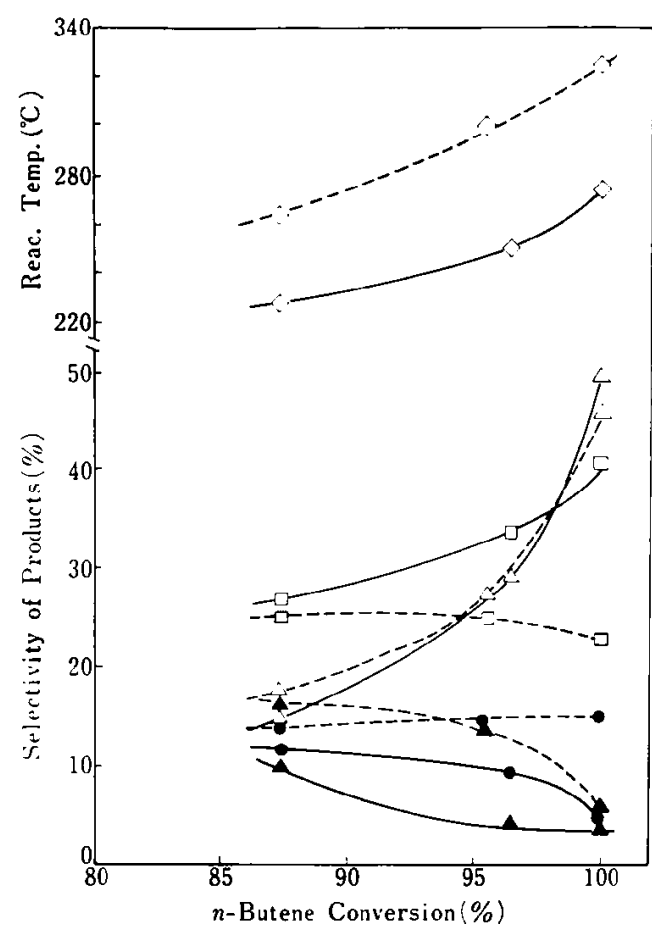

Reaction conditions and notations as in Fig. 5 -; $\mathrm{V} / \mathrm{Cr}(5 / 5)$ preparation as $\mathrm{Cr}-1,---; \mathrm{V}_{2} \mathrm{O}_{5}$

Fig. 7 Relation between Conversion of $n$-Butene and Selectivity of Products over $\mathrm{V} / \mathrm{Cr}$ and $\mathrm{V}_{2} \mathrm{O}_{5}$

conversion of temperature although in the oxidation of 1-butene over V-Sn-W (1: $1: 0.5)$, Kane$\left.\mathrm{ko}^{7}\right)$ found a different result, that is, the selectivity to $\mathrm{AcOH}$ only depended on the reaction temperature and not on the conversion of l-butene and contact time. The increased selectivity was not explicable from the decrease in the selectivity of $\mathrm{AcH}$ with conversion. There may be other intermediates giving $\mathrm{AcOH}$ beside $\mathrm{AcH}$, for example, MEK, biacetyl, acetone and etc. Which were produced with lower selectivity than that of $\mathrm{AcOH}$ as shown in Table 3.

Because of low selectivity of these intermediates they were not analyzed.

The material balance of the main products, which were $\mathrm{CO}, \mathrm{CO}_{2}, \mathrm{AcH}, \mathrm{AcOH}$ and other acid, was only $73 \sim 90 \%$ for $\mathrm{V}-\mathrm{Cr}(5: 5)$ and $64 \sim 99 \%$ for $\mathrm{V}_{2} \mathrm{O}_{5}$. The deviation of the material balance from $100 \%$ was large at low conversion levels. This finding indicates the existence of small quantities of various intermediates giving $\mathrm{AcOH}$ or other products. Figure 8 shows the relationship between conversion of $n$-butenes and selectivity of products over $\mathrm{V}-\mathrm{Ti}(4: 6)$ catalyst over which $\mathrm{AcOH}$ was obtained from $n$-butenes with good selectivity that was next 


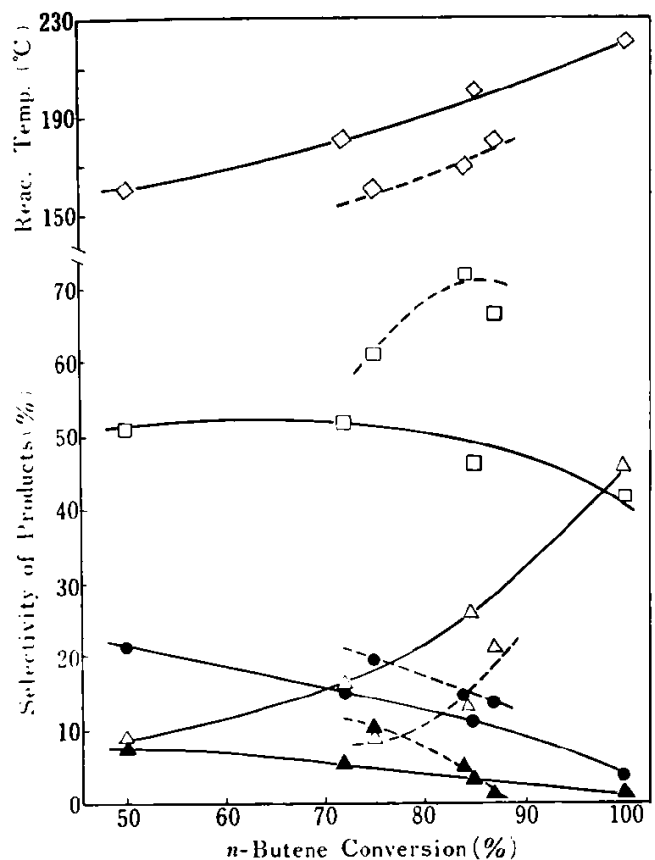

Cat.; $14 \mathrm{~m} l$, Feed; $n$-Butene : air : $\mathrm{H}_{2} \mathrm{O}=1.1$ : $36: 63,-; \mathrm{SV}=1,700 \mathrm{hr}^{-1},---; \mathrm{SV}=420 \mathrm{hr}^{-1}$, Notations as in Fig. 5

Fig. 8 Relation between Conversion of $n$-Butene and Selectivity of Products over V/Ti(4/6)

to that over V-Cir catalyst (Fig. 4). The oxidation of $n$-butenes was carried out under more moderate conditions than these of above. The maximum selectivity to $\mathrm{AcOH}$ was obtained before the complete conversion of $n$-butenes differing from that over $\mathrm{V}-\mathrm{Cr}$ catalyst, that is, the maximum selectivity to $\mathrm{AcOH}$ was $72 \%$ at $84^{\circ}$ o conversion of $n$-butenes. The deviation of the material balance from $100^{\circ}{ }_{0}$ was observed at low conversions of $n$-butenes as in the case of V-Cr catalyst, and the deviation diminished with increasing conversion of $n$-butenes.

In the oxidation of 1-butene over V-X, VSu-X and V-Sn-W catalysts ${ }^{7}$, the deviation of material balance was similarly observed.

\subsubsection{Oxidation of MEK and Diacetyl}

The reactivity of MEK and diacetyl over $\mathrm{V}_{2} \mathrm{O}_{5}$ catalyst was studied to compare with the reactivity of $n$-butenes or sec- $\mathrm{BuOH}$, because MEK and diacetyl were supposed to be the plausible intermediates to form $\mathrm{AcOH}$ from $n$-butenes. At low temperatures where $\sec -\mathrm{BuOH}$ could not be dehydrated, only a trace of MEK was detected by gas chromatography. At high temperatures, MEK could not be detected by gas chromatography and $s e c-\mathrm{BuOH}$ was completely dehydrated to $n$-butenes. These facts
Table 5 Oxidation Over $\mathrm{V}_{2} \mathrm{O}_{6}$ Catalyst

\begin{tabular}{|c|c|c|c|c|c|c|}
\hline & \multirow{2}{*}{$\begin{array}{l}\text { Temp. } \\
\left({ }^{\circ} \mathrm{C}\right)\end{array}$} & \multirow{2}{*}{$\begin{array}{c}\text { Conv. } \\
(\%)\end{array}$} & \multicolumn{4}{|c|}{ Selectivity $(\%)$} \\
\hline & & & $\mathrm{AcOH}_{\mathrm{C}}$ & MA & $\mathrm{CO}+\mathrm{CO}_{2}$ & $\mathrm{AcH}$ \\
\hline $\begin{array}{c}\left.\mathrm{C}=\mathrm{C}-\mathrm{C}-\mathrm{C}^{\mathrm{a}}\right) \\
\left.\mathrm{C}-\mathrm{C}=\mathrm{C}-\mathrm{C}^{\mathrm{a}}\right) \\
\mathrm{OH} \\
\left.\mathrm{I}-\mathrm{C}-\mathrm{C}-\mathrm{C}^{\mathrm{a}}\right)\end{array}$ & 345 & 47.2 & 7.2 & 22.4 & 35 & 10 \\
\hline 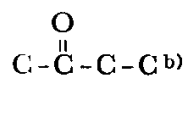 & $\begin{array}{l}285 \\
220\end{array}$ & $\begin{array}{l}96.0 \\
95.0\end{array}$ & $\begin{array}{l}26.9 \\
65.6\end{array}$ & & $\begin{array}{l}35 \\
12\end{array}$ & $\begin{array}{l}0 \\
0\end{array}$ \\
\hline $\begin{array}{c}O \\
C-\stackrel{\|}{C}-\stackrel{\Perp}{C}-C^{b)}\end{array}$ & $\begin{array}{l}285 \\
265\end{array}$ & $\begin{array}{l}89.0 \\
86.5\end{array}$ & $\begin{array}{l}70.5 \\
70.0\end{array}$ & & $\begin{array}{r}15 \\
8\end{array}$ & $\begin{array}{l}0 \\
0\end{array}$ \\
\hline
\end{tabular}

a) Cat.; $4 \mathrm{ml}$, sec-BuOH (Butene) : air : $\mathrm{H}_{2} \mathrm{O}=1.1$ : 44:55, SV $=27,000 \mathrm{hr}^{-1}$

b) Cat., $4 \mathrm{~m} l, \operatorname{MEK}$ (diacetyl) : air : $\mathrm{H}_{2} \mathrm{O}=1.2: 40$ : $59, \mathrm{SV}=5,800 \mathrm{hr}^{-1}$

suggest that $\sec -\mathrm{BuOH}$ is not present in the vapor phase and even if it is present, most of it will be strongly adsorbed on the surface of the catalyst.

Table 5 shows the results of oxidation of $n$-butene, MEK and diacetyl. The oxidation of MEK proceeded under more moderate conditions than those of $\sec -\mathrm{BuOH}$ or $n$-butene. At $285^{\circ} \mathrm{C}$, the conversion of $\mathrm{MEK}$ was $96 \%$ and the selectivity to $\mathrm{AcOH}$ was $26.9 \%$. Under moderate conditions the selectivity to $\mathrm{AcOH}$ increased to $66 \%$ at $95 \%$ conversion of MEK. Only a trace of diacetyl was detected by gas chromatography. On the other hand, diacetyl was more easily oxidized than MEK to give $\mathrm{AcOH}$ with selectivity of $70^{\circ}{ }_{0}$ at $86.5 \%$ conversion. This finding was in accord with the fact that sec-BuOH, MEK and diacetyl were not detected in the oxidation of $n$-butenes.

\subsubsection{Oxidation of Ethylene, Propylene and Butadiene}

In previous papers, $\mathrm{AcOH}$ was produced from ethylene ${ }^{8)}$ and propylene ${ }^{9}$ via catalytic oxidation with air over solid acid catalysts containing molybdic acid or tungstic acid. Ozaki et al. ${ }^{10)}$ found that olefins and alcohols were oxidized to ketone with good selectivity over $\mathrm{Mo}-\mathrm{Sn}$ and $\mathrm{Mo}-\mathrm{Co}$ catalysts coproducing $\mathrm{AcOH}$ and $\mathrm{AcH}$ in low yields.

With regard to $\mathrm{V}_{2} \mathrm{O}_{5}$-binary catalysts, thesc catalysts may be good ones for producing $\mathrm{AcOH}$ from ethylene or propylene as from butenes, since they have strong activity for oxidation of

Volume 18, No. 2, November 1976 


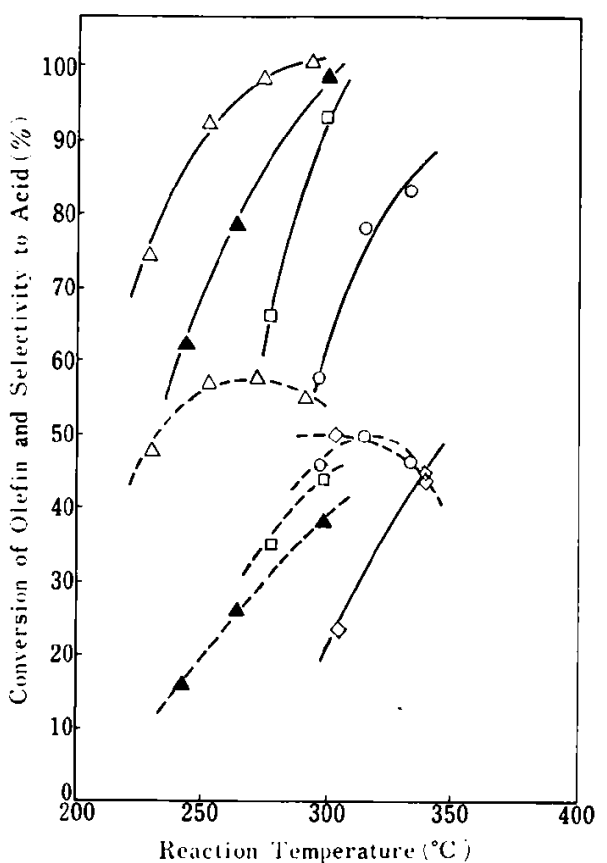

Cat.; $4 \mathrm{~m} l \mathrm{~V} / \mathrm{Cr}(5 / 5)$ preparation as $\mathrm{Cr}-1$ Feed olefin : air : $\mathrm{H}_{2} \mathrm{O}=1.33: 44: 55, \mathrm{SV}=5,600 \mathrm{hr}^{-1}$ $\triangle$; $n$-Butene, $\square$; Isobutene, $\mathbf{\Delta}$; Butadiene, $O$; Propylene, $\diamond$; Ethylene, -; Conversion, ---; Selectivity

Fig. 9 Reactivity of Olefins and Selectivity to Acid over V/Cr Catalyst

MEK to $\mathrm{AcOH}$ than the above $\mathrm{MoO}_{3}-\mathrm{SnO}_{2}$ and $\mathrm{MoO}_{3}-\mathrm{Co}_{2} \mathrm{O}_{3}$ catalysts.

Figure 9 shows the results of oxidation of olefins over $\mathrm{V}-\mathrm{Cr}(5: 5)$ catalyst. The reactivity of each olefin decreased with the shortening of the chain length. This tendency is like that of hydration of olefins. As would be exepected, ethylene and propylene formed $\mathrm{AcOH}$ with good selectivity as butenes. Butadiene formed only MA, and it did not form methyl vinyl ketone, diacetyl and $\mathrm{AcOH}$, which should be obtained if butadiene was oxidized according to Scheme 1 .

The selectivity to acid from these olefins increased with increasing conversion or reaction temperature as shown in the case of butenes. Each olefin had its critical temperature at which it gave acid with maximum selectivity. These results suggest that, with $\mathrm{V}-\mathrm{Cr}$ catalyst, $\mathrm{AcOH}$ is formed from each olefin by consecutive oxidation. Mono-olefins may be oxidized in the reaction paths shown in Scheme 1 and 2. Even if a catalyst is effective for hydration of olefins and oxydehydrogenation of alcohols as $\mathrm{V}-\mathrm{Cr}$ catalyst, it also has the active site that is effective for allylic type oxidation of olefins, as seen from the presence of a small amount of MA always accompaning $\mathrm{AcOH}$ in the oxidation of $n$-butenes. Therefore, butadiene was oxidized to MA via allylic type oxidation and not to $\mathrm{AcOH}$ via oxydehydrogenation.

As to the oxidation mechanism of butenes over various catalysts, four mechanism have been proposed. (i) The formation of an allyl radical intermediate to produce butadiene, MA or methacrolein. (ii) The formation of an alcoholic intermediate by hydration of the carbonium ion intermediate to produce MEK, $\mathrm{AcH}$ and $\mathrm{AcOH}^{10), 12)}$. (iii) The formation of a $\pi$-complex with the oxide surface and the subsequent scission of the carbon-carbon double bond of butenes with nickel oxide and cobalt oxide catalysts ${ }^{13)}$. (iv) The formation of an $\sigma$-complex by nucleophilic attack of hydroxyl anion as accepted for oxypalladation of $n$-butene to form MEK ${ }^{14}$.

From the product patterns in the oxidation of sec- $\mathrm{BuOH}$ over various $\mathrm{V}_{2} \mathrm{O}_{5}$-binary catalysts as shown in Fig. 4, the properties of a catalyst changed with a second element. That is, V-Mo $(5: 5), \mathrm{V}-\mathrm{Mn}(8: 2), \mathrm{V}-\mathrm{P}(7: 3)$ and $\mathrm{V}-\mathrm{AI}$ $(9: 1)$ catalysts were effective to producing MA by mechanism (i). With V-Pd (98.3:1.7) catalyst, the selectivity to MA was reduced to $5 \%$ but that to $\mathrm{AcOH}$ was increased to $38 \%$ in comparision with $\mathrm{V}_{2} \mathrm{O}_{5}$ catalyst in spite of a little addition of palladium. In this case, $\mathrm{AcOH}$ may be obtained partly by mechanism (iv). With V-Rh (5:5), V-Cr $(3: 7), \mathrm{V}-\mathrm{Ti}(4: 6)$ and $\mathrm{V}-\mathrm{Nb}(5: 5)$ catalysts the selectivity to $\mathrm{MA}$ was low and the selectivity to $\mathrm{AcOH}$ was increased markedly by a second element. In these catalysts, AcOH may be obtained by mechanism (ii) or (iii).

As $s$ representive catalyst that was effective to form $\mathrm{AcOH}$ from $n$-butenes and isobutene, $\mathrm{V}-\mathrm{Cr}$ catalyst was studied comparing it with the $\mathrm{V}_{2} \mathrm{O}_{5}$ catalyst, as described in 3.4.1 3.4.5, mainly in reference to the reactivity of various olefins and plausible intermediates. Mechanism (ii) is the most plausible one to explain the reaction path of $\mathrm{AcOH}$ formation from $n$-butenes, isobutene, propylene and ethylene, but still sufficient experimental data are lacking to disregard mechanism (iii).

\section{References}

1) Moro-oka, Y., Takita, Y., Ozaki, A., Bull. Chem. Soc. Japan, 44, 293 (1971).

2) Brockhaus, R., Chemie Ing. Tech., 38, 1,039 (1966). 
3) Bretton, R. H. et al., Ind. Eng. Chem., 44, 594 (1952).

4) Nihon Gosei, Japan 45-30,802; 31,165; 41,367; 41,$570 ; 41,571 ; 41,569$ (1970). Ajinomoto, Japan 4710,691 (1972), U.S. $3,704,317$ (1972), Brit. 1,234,896 (1971), Toa Nenryo Kogyo, Japan 49-40,446 (1974), Kurarey, Japan 47-10, 692 5 (1972).

5) Mactadyen, D. A., J. Boil. Chem., 158, 107 (1945). 6) JISK-1,351 (1956).

7) Kaneko, K. et al., Bull. Japan Petol. Inst., 16, 17(1974).

8) Societe Edison, Ital., 640,456 (1962); Ruhchemie,
Fr., 1,395,378 (1965).

9) Buitin, J. J. Catalysts, 10, 188 (1968), Japan 40-8,523, 10,569 (1965).

10) Moro-oka, Y., Tan, S., Ozaki, A., Bull. Chem. Soc. Japan, 41, 2,820 (1968); J. Catalysis, 12,291 (1968); 17, 125,132 (1970).

11) Batist, Ph. A. et al., J. Catalysis, 5, 55 (1966).

12) Takita Yu. et al., Shokubai, 18, 13 (1976).

13) Moro-oka Y. et al., J. Am. Chem. Soc., 89, 5124 (1967).

14) Henry P. M., ibid., 86, 3246 (1964). 